\title{
Developing Cognitive Academic Language Proficiency: The Journey
}

\author{
Hetty Roessingh, Pat Kover, and David Watt
}

This study tracks the development of cognitive academic language proficiency of 47 academically competent high school ESL learners of differing age on arrival $(A O A)$ who received instructed ESL support and one comparison group of six young arrivals who received little if any ESL support during their educational experiences. Although intake and outcome measures appear similar on the surface for all 47 students, variability in the subscores of the outcomes measure provided the catalyst for taking a closer look at progress during the ESL program. The outcomes provide a refined understanding of the development of cognitive academic language proficiency, and in particular the role of underlying proficiency and structured ESL support. The data suggest that the youngest arrivals (i.e., those aged 6-11) remain at risk in their postsecondary education. The outcomes also suggest that the acquisition of cultural capital and metaphoric competence remains a challenge for all learners.

Cette étude trace le développement de l'habileté cognitive en langage académique de deux groupes: d'une part, 47 élèves du secondaire compétents sur le plan académique, apprenant l'anglais comme langue seconde, n'étant pas tous du même âge à leur arrivée au pays et ayant reçu un appui pédagogique en ALS et; d'autre part, un groupe contrôle composé de 6 personnes étant arrivées au pays quand elles étaient jeunes et ayant reçu peu ou pas d'appui en ALS pendant leur formation éducative. À prime abord, les données préliminaires et les indicateurs des résultats semblent similaires pour les 47 élèves; toutefois, des écarts au niveau des notes secondaires des indicateurs des résultats ont suscité une analyse approfondie du cheminement à l'intérieur du programme d'ALS. Les résultats permettent de mieux comprendre le développement de l'habileté cognitive en langage académique et, plus particulièrement, du rôle de la compétence sous-jacente et de l'appui pédagogique en ALS. Les données indiquent que les nouveaux arrivés les plus jeunes (âgés de 6 à 11 ans) demeurent à risque pendant leur éducation postsecondaire. Les résultats révèlent également que l'acquisition d'un capital culturel et d'une compétence métamorphique continue à constituer un défi pour tous les apprenants.

\section{Introduction}

Like many Western countries, Canada faces the challenge of an aging baby boom population, a low birthrate, and a shift to the third economy driven by 
information technology (IT). Canada's response to its human resource needs of the future is visible in its immigration policy. Since 1985 attracting a "brain gain" has been increasingly emphasized (Baxter, 1999). Independent immigrants (both skilled worker and business class with investment capital of up to $\$ 350,000$ ) are given priority (Marshall, 1999). The immigration target is $1 \%$ of the population, or approximately 300,000 newcomers a year. Most of these newcomers to Canada come from Pacific Rim countries. Central to their successful integration into the economy and Canadian culture is the acquisition of English-language proficiency (ELP). For their children-and for Canada's future- the development of enough ELP for successful engagement with the academic demands of high school and entry into tertiary programs of choice (in this case university entrance) is crucial.

This study focuses on the development of cognitive academic language proficiency (CALP) of four cohorts of ESL learners (different age on arrivalAOA) who graduated from high school with grade 12 (academic) English (English 30, required for university entrance), and the programmatic supports that made this academic success possible. It starts with outcome measures (i.e., English 30 examination scores) for these students (Roessingh \& Kover, 2002, 2003) and provides a retrospective of progress reflected in standard reading measures. It is grounded in Cummins' (1982) theoretical framework of cognitive academic language, common underlying proficiency, and the concomitant idea of language threshold for academic success.

Although numerous studies have explored achievement outcomes for ESL learners (Collier \& Thomas, 1999a, 1999b), few studies have explored the development of English-language proficiency required to achieve academically on a par with native-speaking (NS) peers. And although ESL practitioners continue to advocate for ESL programming, we lack the crucial understanding of threshold levels required for academic proficiency in relation to the programmatic supports that may account for the educational achievement of ESL learners (De Avila, 1997).

Our orienting questions are as follows.

1. Are there distinct language thresholds for successful completion of successive grade levels in high school as determined by a standardized reading measure?

2. What kinds of assessment instruments provide the best reflection of (ELP) requirements for academic progress and achievement?

3. What programmatic and instructional supports are critical to the development of ELP and the level of achievement on high-stakes tests required for entry into postsecondary studies?

4. What is the role of common underlying proficiency in the educational outcomes for different AOA?

We begin by providing a theoretical framework for our work. Then we provide background information to give the reader a context for this study: 
Queen Elizabeth High School, the ESL learners, and the ESL program. We briefly describe achievement outcomes for ESL learners on the grade 12 English examination: the catalyst for the current study. We describe the methodology, present the findings by way of four trajectories, and discuss the findings in the light of the four orienting questions. We conclude with a call for all those involved in educational decision-making for ESL learners to use this information to enhance opportunities for academic success for these students, especially in the area of policy reform.

\section{Theoretical Framework}

\section{Development of CALP}

Cummins $(1982,1999)$ posited the conceptual framework of basic interpersonal communication skills (BICS) and cognitive academic language proficiency (CALP) as these relate to the overall development of academic achievement for ESL learners. The terms BICS and CALP were coined to describe language use in contexts that increasingly move from the here and now to abstract uses of language that require language itself. In a similar vein, noted literary critic Frye (1963) described the uses of language needed for conversation (nouns and adjectives for naming things), information (verbs, or words for action and movement), and imagination (metaphor needed to construct possible models of human experience).

Cummins (1996) writes, "As students progress through the grades, they are increasingly required to manipulate language in cognitively demanding and context-reduced situations that differ significantly from everyday conversational interactions" (p. 58). The terms BICS and CALP have become popularized and have found their way into the conventional wisdom of ESL practitioners as well as mainstream teachers (Shoebottom, 2001). However, researchers have created variously interpreted of the conventional view of the BICS-CALP continuum (Chamot \& O'Malley, 1987; Nation, 2001; Coelho, 2003). Cummins himself has shifted his position as he has sought to explain options for accelerating the development of ELP for educational purposes. Our position is that each of the four quadrants plays a critical role in the development of CALP. At a macro level we find Cummins' framework useful for thinking about the continuum of language development as it relates to the program design and development that we present in this article.

Over the past two decades, second-language acquisition studies have contributed to the development of theoretical and research perspectives on the general question, How long does it take to achieve English language proficiency for school? Variables such as AOA, level of L1 proficiency, level of L2 proficiency on arrival, and length of residence have emerged as significant predictors of the varying lengths of time that may be required to 
attain similar levels of content area achievement. The results of these studies (Cummins, 1982; Collier, 1987/1988, 1992, 1995; Twyford, 1987/1988; Klesmer, 1994) are remarkably consistent in their estimates of the time required for ESL learners to perform academically at grade level with their NS counterparts. ESL practitioners now generally recognize that it will take ESL learners approximately two years to develop communicative competence (BICS), and even with instructed support five to seven years to develop the level of language proficiency required to compete on a par academically with their NS counterparts. As we explain in this study, instructed support over time is a crucial variable that made the documented progress and outcomes possible.

\section{Common Underlying Proficiency (CUP)}

Common underlying proficiency theory posits that experience with either L1 or L2 can promote the development of the proficiency underlying both languages given adequate motivation and exposure to both either in school or in the wider environment. Cummins (1996) uses the metaphor of a dual iceberg to represent this concept. CUP is relevant to the study at hand because we were working with learners in high school of differing AOA (i.e., aged 6-11, 12-14, and 15-17). Younger arrivals are less developed cognitively and linguistically than their older-arriving classmates, and as they mature in the English-speaking milieu of school, they may have diminished potential for using their L1 as a springboard for concept and language development in English. This variable emerged as having a clear effect on achievement levels as reflected in the subscores of the English 30 examination (Roessingh \& Kover, 2003), the trigger for our current investigation.

\section{Thresholds for Academic Achievement}

As noted above, the development of CALP-level proficiency is a long and uneven process. ESL learners are continually chasing a moving target in their effort to close the gap between themselves and their NS classmates sufficiently to compete academically: many, if not most, never do (Collier, 1992; Thomas \& Collier, 2002). The language demands (i.e., thresholds) for demonstrating educational achievement increase with each year of academic progress. The question at hand, therefore, relates to the connection between language proficiency, academic progress, and instructed ESL support. We may measure language proficiency with a standardized reading instrument, as we explain below, with the caution that the relationship between language proficiency and academic achievement is not always linear, and there appears to be a ceiling effect. In other words, there is a point at which language proficiency ceases to be a predictor of academic achievement. We elaborate on this point in our findings. 
High school students who aspire to a university education (as do the ESL students at Queen Elizabeth High School) must meet increasingly rigorous admissions requirements. Seat space in universities across Canada is at a premium, and only the best academic students are currently accepted. At the University of Calgary, for example, the grade average of first-year students has increased from 65\% in 1995 to 82.3\% in 2003 (Tetley, 2004). Simon Fraser University and the University of British Columbia in Vancouver and the University of Toronto and Queen's in Ontario have similar requirements.

ESL learners, therefore, must also be able to demonstrate this level of academic performance, which includes an English proficiency requirement as demonstrated by a minimum blended mark of 50\% in English 30 (i.e., half of this mark is awarded by the grade 12 English teacher; the other half is derived from the departmental examination mark) and a pass mark in the Effective Writing Test (set by the University of Calgary); or $75 \%$ in the grade 12 English departmental examination; or a blended mark of $80 \%$ in grade 12 English. How well a prospective university (ESL) student needs to read in order to perform at this level is an important question we seek to address in the current study. Our goal of $60 \%$ on the departmental English examination was our estimate for a minimal performance threshold (equivalent to approximately the 65th percentile on a standard reading measure) that would reflect adequate ELP for university (entrance) level studies. Obviously this would require exceptional marks in the other subject areas to meet the overall grade average for university admission.

We note that in mathematics and sciences, ESL learners generally score significantly higher than their NS peers-as they must - to achieve the overall academic average required for entry into university programs (Roessingh, Ehler, Watt, \& Nettel-Aguirre, 2004).

De George (1987/1988) notes various thresholds across the United States for ESL learners leaving bilingual/ESL programs. Texas, for example, sets a percentile score of 40 on a standardized achievement test of reading and vocabulary. In California the 36th percentile is used as the criterion for exit; in New York it is the 23rd percentile. More recently Garcia (2000) observed a shift to a time limit in California rather than an achievement criterion for exit from an ESL program. As a consequence of a 1998 ballot initiative (English Language Education for Immigrant Children, 2001), California's English-only mentality promotes the accelerated placement of ESL learners in mainstream settings. In California, ESL support is now limited to one year. Oklahoma provides three years of support, the apparent rationale (following the example of California) being that ESL learners need to be integrated into mainstream classes as soon as possible.

On the evidence of large-scale studies of student achievement-admittedly from databases at some remove from school programs-tracked over the past 15 years, Collier and Thomas (1999c) observe that ESL learners score at 
approximately the 10th percentile of the general population on standardized school district tests of all school subjects after two to three years of exposure to English. As a group nationwide they graduate from high school still at the 10th percentile or leave school without graduating.

In at least two Canadian provinces-Ontario (Ministry of Education and Training, Ontario, 1999) and Alberta (Alberta Learning, 2002)-ESL support at the high school level is structured around course credits (5 levels in both provinces) that equate to approximately 550 contact hours in Ontario and 625 hours in Alberta (of which only levels 2, 3, and 4-375 hours-are credited). Regardless of whether educational support is calculated by levels, percentile rank, or number of contact hours or where students reside, it does not change the need for ESL students to have reached a high level of CALP-like proficiency to meet the achievement requirements for admission to university. It is clear from the data presented above that the challenge facing ESL learners (and their teachers) to develop this level of ELP is overwhelming.

\section{Background}

\section{Queen Elizabeth High School and ESL Learners}

We are a collaborative group of colleagues: ESL academics and practitioners and English language arts teachers working together at Queen Elizabeth High School in Calgary, Alberta. Our school is a small, academically oriented high school with an enrollment of approximately 800 students in grades 10-12. An ESL program was introduced in September 1997 in response to the growing numbers of students arriving from the Pacific Rim, largely the children of business class and skilled worker immigrants who had goals for university attendance in the future. Most of the ESL students arrived directly from overseas in their grade 10 year aged 15-16. Over the five-year span of our study, intake from junior high schools in our feeder system (those who arrived aged 12-14) and even from elementary school (those who arrived aged 6-11) began to change the learner profile of the ESL program.

Although all the students arrived in high school with intermediate-range skills (reading equivalent of grade 5, approximately the 15th percentile), the effect of the variability in their first language (L1) proficiency did not go unnoticed (Roessingh \& Kover, 2003). A key realization for us was that the younger arrivals did not have a fully developed L1 that could act as a springboard for cognitive development in English, their second language (L2). Similar to DeVries' (1999) findings, we noted a gradual loss, or at a minimum a low plateau in L1 ("kitchen Chinese") and the inability of L2 to overcome this low plateau to any significant extent, resulting in schoolyard English. Although these younger arrivals sounded good in English, this was a disadvantage in the sense that their communicative competence was often mistaken as evidence of full academic language proficiency. Table 1 provides 
Table 1

Profile of Four Cohorts of ESL Learners (Successful Graduates): 1997-2002, $N=53$

\begin{tabular}{|c|c|c|c|}
\hline Cohort & $\begin{array}{l}\text { Immigrant } \\
\text { Class }\end{array}$ & $\begin{array}{l}\text { Age on } \\
\text { Arrival }\end{array}$ & Risk Profile \\
\hline $\begin{array}{l}A \\
N=6\end{array}$ & $\begin{array}{l}\text { Business } \\
\text { and skilled } \\
\text { worker }\end{array}$ & $\begin{array}{l}\text { Elementary } \\
\text { aged 6-11 }\end{array}$ & $\begin{array}{l}\text { Little or no ESL support. Academic expectations but } \\
\text { marginal performance throughout high school in English } \\
\text { literature courses. Approximate reading grade equivalent } \\
\text { (GE) } 5 \text { on entry into grade } 10 \text {. Failure and dropout of } \\
\text { program at university level. }\end{array}$ \\
\hline $\begin{array}{l}\mathrm{B} \\
N=8\end{array}$ & $\begin{array}{l}\text { Business } \\
\text { and skilled } \\
\text { worker }\end{array}$ & $\begin{array}{l}\text { Elementary } \\
\text { aged 6-11 }\end{array}$ & $\begin{array}{l}\text { Little or no ESL support. Academic expectations. At risk } \\
\text { for academic failure in high school. Approximate reading } \\
\text { GE } 5 \text { on entry into grade } 10 \text {. ESL support offered to this } \\
\text { cohort for grades } 10-12 \text {. }\end{array}$ \\
\hline $\begin{array}{l}\mathrm{C} \\
N=18\end{array}$ & $\begin{array}{l}\text { Business } \\
\text { and skilled } \\
\text { worker }\end{array}$ & $\begin{array}{l}\text { Junior } \\
\text { High aged } \\
12-14\end{array}$ & $\begin{array}{l}\text { Varying amounts and types of ESL support. Academic } \\
\text { expectations. At risk for academic failure in high school. } \\
\text { Approximate reading GE } 5 \text { on entry into grade } 10 . \text { ESL } \\
\text { support offered throughout grades } 10-12 \text {. }\end{array}$ \\
\hline $\begin{array}{l}D \\
N=21\end{array}$ & $\begin{array}{l}\text { Business } \\
\text { and skilled } \\
\text { worker }\end{array}$ & $\begin{array}{l}\text { Senior } \\
\text { High aged } \\
15-17\end{array}$ & $\begin{array}{l}\text { New arrivals to Canada. Academically competent, in a } \\
\text { hurry to go to university. Approximate reading GE } 5 \text { on } \\
\text { arrival. ESL program designed to support academic } \\
\text { goals. }\end{array}$ \\
\hline
\end{tabular}

Note. Readers who have been following this research in the TESL Canada Journal over the years may have noticed two additional students in Cohort D. These two graduated in June 2002, and they represent the last of the intake cohorts from 1997-1999, bringing this number from 19 to 21 . Their outcomes were consistent with those of the cohort as a whole (published previously).

a summary of the four cohorts of learners in our study and takes AOA as the key variable. Note that Cohort $\mathrm{A}$ is a comparison group of six elementary school-aged (6-11) arrivals who received little if any ESL support and who graduated in 1998, the year the ESL program was implemented at the school.

Approximately 60 students participated in the program during the three intake years (1997, 1998, 1999). By June 2002 all 47 ESL students who attempted English 30 had passed the course, a requirement for university entrance. This represents a retention rate (i.e., movement forward from grade 10 to 12 ) of approximately $78 \%$ (i.e., 47 of 60 ), an unusually high rate compared with the $50 \%$ retention rate recorded by Watt and Roessingh (2001) for this profile of ESL learner. Furthermore, it represents an exceptional participation rate as reflected in student registration in both English and mathematics 30; and finally a success rate of $100 \%$ (i.e., no failures) in grade 12 English 30 (Roessingh, 2004).

We have published a series of articles about our work at Queen Elizabeth High School (Roessingh, 1999, 2004; Roessingh \& Field, 2000; Roessingh \& 
Kover, 2002, 2003) that provide details about the program, the timetable, and achievement outcomes. We encourage readers who may be interested in this work to consult these sources. In the following section we provide a brief description of the ESL program.

\section{The ESL Program at Queen Elizabeth High School}

In contrast to content-driven or weak language-through-content (LTC) models (Mohan, 1990; Chamot, 1995; Chamot \& O'Malley, 1987, 1994) we have adopted a strong version of LTC. Language learning is the focus of our instructional planning: content is the vehicle. We believe in the direct, intentional, and targeted teaching of language objectives in our curriculum decision-making. In addition, we include in our curriculum framework direct strategies instruction and mediation of underlying concepts. Most significant, the development of cognitive academic language proficiency depends on our learners developing a critical mass of vocabulary and becoming good readers. This requires explicit instruction.

Integrated thematic units were prepared for the first two levels of the ESL program. Interest and relevance to teenagers, embeddedness of cultural information, textual support for the acquisition of grammar and vocabulary and the deployment of beginning reading strategies, potential for designing communicative tasks, integration of authentic materials, and linkage to mainstream curriculum were criteria we used when preparing these units. (Interested readers may find samples of these units at www.LearningByDesign.ucalgary.ca)

For the third level, content was negotiated, selected, and prepared collaboratively by the ESL and the grade 10 (sheltered) English teacher (Roessingh, 1999). For the last two levels (the tutorials), the ESL learners were fully integrated, and tutorials were designed to support the mainstream English teachers' choice of content and work assignments.

The ESL program extended over five semesters and provided 625-750 contact hours of support to the students, beginning at the high intermediate level. Alberta Learning, the provincial ministry of education, credits only 375 of these hours. The shortfall was reallocated internally to the ESL program by the school administration or was realized through strategic timetabling that turned out to be cost-neutral (Roessingh \& Field, 2000). Appendixes A and B give details of the ESL program and the timetable. Table 2 provides a snapshot of the program progression over the five semesters.

\section{Achievement in the Grade 12 English Language Arts Examination}

We noted above that English 30 is a high-stakes course: it is the single course required for entry into all programs of study at university and thus performs a gatekeeping function. In our province, as in many educational jurisdictions across Canada and increasingly the US (Garcia \& Gopal, 2003), English 30 is 
Table 2

Program Progression for ESL Learners

\begin{tabular}{|c|c|c|c|}
\hline ESL Placement & Date & $\begin{array}{l}\text { ESL Program } \\
\text { Focus }\end{array}$ & $\begin{array}{l}\text { Assessment } \\
\text { Measures }\end{array}$ \\
\hline Intermediate ESL & $\begin{array}{l}\text { Sept.-Jan. (fall } \\
\text { semester, grade 10) }\end{array}$ & $\begin{array}{l}\text { Conversational } \\
\text { English/skills } \\
\text { booster 125-250 } \\
\text { hours }\end{array}$ & $\begin{array}{l}\text { SLEP }^{1} \text { Gates MacGinitie } \\
\text { Diagnostic Reading } \\
\text { Program }^{3}\end{array}$ \\
\hline Advanced ESL & $\begin{array}{l}\text { Feb.-June (winter } \\
\text { semester, grade 10) }\end{array}$ & $\begin{array}{l}\text { Transitional } \\
\text { Academic Skills } \\
125 \text { hours }\end{array}$ & $\begin{array}{l}\text { SLEP Gates MacGinitie } \\
\text { DRP }\end{array}$ \\
\hline Transitional & $\begin{array}{l}\text { Sept.-Jan. (fall } \\
\text { semester, grade 11) }\end{array}$ & $\begin{array}{l}\text { Sheltered English } \\
10125 \text { hours } \\
\text { Adjunct ESL block } \\
125 \text { hours }\end{array}$ & $\begin{array}{l}\text { Gates MacGinitie Final } \\
\text { exit portfolio and } \\
\text { conference }\end{array}$ \\
\hline Mainstreamed & $\begin{array}{l}\text { Feb.-June (winter } \\
\text { semester, grade 11) }\end{array}$ & $\begin{array}{l}\text { Tutorial to support } \\
\text { grade } 11 \text { English } \\
125 \text { hours }\end{array}$ & $\begin{array}{l}\text { Final exit portfolio and } \\
\text { conference }\end{array}$ \\
\hline Mainstreamed & $\begin{array}{l}\text { Sept.-Jan. (fall } \\
\text { semester, grade 12) }\end{array}$ & $\begin{array}{l}\text { Tutorial to support } \\
\text { grade } 12 \text { English } \\
125 \text { hours }\end{array}$ & $\begin{array}{l}\text { Final exit portfolio and } \\
\text { conference provincial } \\
\text { exam TOEFL }{ }^{4} \text { CLBA }^{5}\end{array}$ \\
\hline
\end{tabular}

${ }^{1}$ Secondary Level English Proficiency, Educational Testing Service, 1980;

${ }^{2}$ MacGintie \& MacGinitie, reading tests (1992a);

${ }^{3}$ Diagnostic Reading Program, Alberta Education, 1986;

${ }^{4}$ Test of English as a Foreign Language, Educational Testing Service, 1999;

${ }^{5}$ Canadian Language Benchmarks, Citizenship and Immigration Canada, 1996.

accompanied by a mandatory examination set by the provincial ministry of education, in our case Alberta Learning. For ESL learners the English 30 examination poses a formidable challenge because they study for it in English while still learning the language.

The outcomes in English 30 for the ESL learners shown in Table 1 have been recorded in other publications (Roessingh \& Kover, 2002, 2003). Perhaps the most striking feature of these data is the convergence toward $60 \%$ for all ESL learners who received direct ESL support (i.e., cohorts B, C, and D). Second, we noted the impressive distance the youngest arrivals (cohort $B$ ) were able to traverse to achieve a mark of $60 \%$ given their initial reading GE of 5 and their lack of underlying proficiency to advance their cognitive academic language proficiency in English. Although the outcomes for these students appeared to converge toward a mark of $60 \%$ for learners of all AOA, further examination of the subscores revealed unevenness in the composition of the final mark. Last, we were puzzled by the ceiling effect at $60 \%$ for all cohorts who received instructed support. We wondered about the role of 
cultural information and metaphoric competence in the composition of the English examination and the relationship between ELP and the ability to score well on a content examination such as English 30. These concerns triggered the current investigation.

A few of the older arrivals were required to write the TOEFL examination for university entry. Several also participated in a study conducted by local researchers Watt and Lake (2000) comparing TOEFL scores with Canadian Language Benchmarks (CLB) scores. We note that ESL high school graduates who score $58 \%$ or better on the English 30 examination score approximately 230 on the TOEFL. The University of Calgary, for example, requires a score of 220 to demonstrate ELP sufficient for entry into undergraduate programs, a threshold that a mark of approximately $60 \%$ in English 30 will satisfy. The students scored on benchmarks 7 and 8 on the CLB. The Southern Alberta Institute of Technology (SAIT) in Calgary permits the CLB as an alternative to the TOEFL and a grade 12 English course for entry into its programs. Students must score on benchmark 8 to fulfill entry requirements. Again, it would appear that $60 \%$ on English 30 meets this requirement. For many high school students, however, who have difficulty with a literature-based course, an alternative way of fulfilling the ELP requirement for postsecondary school studies may be most welcome.

\section{Methodology}

\section{Procedure}

Our analysis of the English 30 data led us to recognize the significance of AOA on learning outcomes. Although all 47 students taking ESL classes were initially placed as intermediate-level learners (reading GE 5) and ultimately scored similar marks on the English 30 examination, we noted the uneven profile of achievement in the subscores. We sought to reconstruct the trajectory of learning from intake to outcome by accessing information in the students' cumulative records together with records of assessment kept from the ESL program (highlighted in the right hand column of Table 2).

Researchers in the field (Saville-Troike, 1991; Collier, 1992) observe that reading scores may be the single best predictor of academic progress and achievement and a valid predictor of L2 thinking skills at secondary and postsecondary levels. We also chose to track reading achievement as a reflection of academic progress. Consistent documentation of achievement with a single instrument over time was not available until after enrollment in the ESL program in grade 10. Our primary research strategy involved taking data from multiple sources noted above, converting all scores to GE, and averaging the scores for each of the four cohorts. Correlation across the datasets (Roessingh, 1996) suggested that this might be a prudent strategy for pressing all available data for the purposes of this investigation. 


\begin{tabular}{|c|c|}
\hline Test & Comments \\
\hline $\begin{array}{l}\text { CTBS (Canadian } \\
\text { Tests of Basic Skills) }\end{array}$ & $\begin{array}{l}\text { Inconsistently administered on a school by school basis in grades } 3 \text {, } \\
6,9 . \text { We used this information where available. }\end{array}$ \\
\hline $\begin{array}{l}\text { SLEP (Secondary } \\
\text { Level English } \\
\text { Language Proficiency) }\end{array}$ & $\begin{array}{l}\text { Administered upon entry to ESL program. Useful for placement } \\
\text { purposes (rather than exit). 99th percentile corresponds to about a } \\
\text { reading GE of } 6 \text { : too low for placement in academic grade } 10 \text { English } \\
\text { language arts. }\end{array}$ \\
\hline $\begin{array}{l}\text { Gates MacGinitie } \\
\text { Reading Tests, (2nd } \\
\text { ed.1992a) }\end{array}$ & $\begin{array}{l}\text { Consistently administered in ESL program at the beginning and end } \\
\text { of each semester. The } 2 \text { nd ed. norming sample of } 42,000 \text { grades } 1-12 \\
\text { students reflects our changing Canadian demographics. Variety of } \\
\text { scales for conversion of raw scores permits meaningful comparison } \\
\text { and interpretation of scores. Easy to administer. }\end{array}$ \\
\hline $\begin{array}{l}\text { DRP (Diagnostic } \\
\text { Reading Program, } \\
\text { Alberta Education) }\end{array}$ & $\begin{array}{l}\text { Widely recognized and accepted measure in Alberta; useful for } \\
\text { establishing the validity of Gates MacGinitie scores as a measure of } \\
\text { general reading ability. High correlation found between DRP and } \\
\text { Gates MacGinitie scores in previous research (Roessingh, 1996). }\end{array}$ \\
\hline $\begin{array}{l}\text { Provincial } \\
\text { Achievement Tests: } \\
\text { grades } 3,6,9 \\
\text { (Alberta Learning) }\end{array}$ & $\begin{array}{l}\text { Mandatory provincial tests in grades } 3,6,9 \text {. Outcomes are reported in } \\
\text { percentages. The language arts scores were compared with DPR, } \\
\text { Gates MacGinitie, and SLEP scores. } 50 \% \text { on the Language Arts exam } \\
\text { corresponds to approximately a GE } 5 \text { (measured by DRP and Gates } \\
\text { MacGinitie), or approximately the } 12 \text { th to } 15 \text { th percentile. }\end{array}$ \\
\hline
\end{tabular}

\section{Instruments}

Table 3 summarizes the measures used to develop the trajectories of the four cohorts of ESL learners in the study depicted in Figures 1-4.

Reading comprehension scores garnered from the multiple sources shown in Table 3 were mapped against years of educational experience as grade equivalents (GE) rather than percentiles, percentages, NCEs (normal curve equivalents, Collier, 1992), NPRs (National Percentile Ranks, Thompson et al., 2002), or extended scale scores because many mainstream and ESL practitioners can relate to the data more directly this way. Normally, extended scale scores, NCE, or NPR units are used because GEs are not sufficiently refined for research purposes. We are fully aware of the limitations of our data sources and the approach we have chosen: clearly we need consistent instrumentation and administration and interpretation of the tests that are selected. Our purpose at this stage, however, is to make our work accessible to our colleagues in the field by representing it visually. Later we shall see that reading scores in and of themselves do not adequately explain student achievement in language arts. Success across all content areas of the curriculum is beyond CALP. 


\section{Results}

Figures 1-4 and the accompanying text illustrate and explain the learning trajectories of the four cohorts of ESL learners summarized in Table 1: (a) elementary arrivals/little or no ESL support; (b) elementary arrivals/late ESL support; (c) junior high arrivals/with ESL support; (d) senior high arrivals with ESL support.

The hypothesized normal reading development trajectory of a 45-degree angle reflects the expectation of one year of schooling experience to produce a one-year gain in reading comprehension scores.

Note that the rate for initial acquisition of language is steep. Records reflect student scores as high as the 30th percentile on standardized reading measures in the early stages of Division 1 (grades 1-3). ESL learners, for example, may acquire 1,000-2,500 English words in their first year. Their NS counterparts arrive in grade 1 with a vocabulary of approximately 2,500 words and knowledge of the grammar system (Moskowitz, 1978). These results are not dissimilar to results recorded in immersion studies (Lambert, 1969). By grade 3, however, this gap widens further, and by grade 5 we note a gap of 12-36 months. Native speakers develop language at the rate of about 3,000 words per year, a rate that ESL children cannot equal without instructed support. These children often become invisible in the general school population throughout their junior high (Division 3) years because they

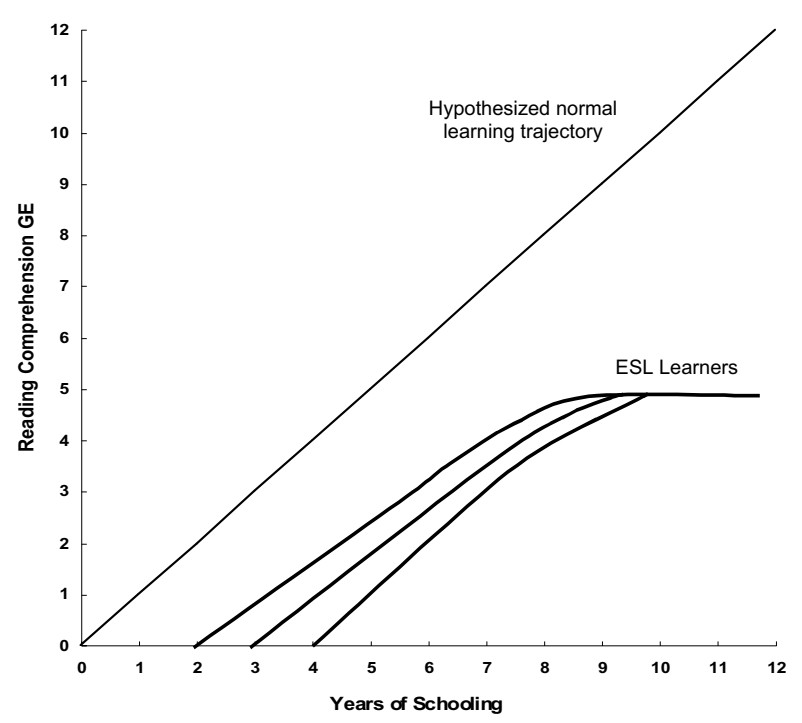

Figure 1. Trajectory of cohort A: young arriving ESL learners schooled in English (little or no ESL support) $N=6$.

Sources: CTBS, Alberta Achievement, Gates-MacGinitie, DRP. 
sound good and have achieved communicative competence that can confound their teachers. We noted that their mathematics scores were about average (Roessingh \& Kover, 2002). Grade 9 provincial achievement results in reading, however, place these students as a group in the 12th-15th percentile, indicating a reading equivalent of approximately GE 5. This would appear to be the limit, then, of language that may be acquired through immersion and content exposure in mainstream settings. With no instructional intervention, they may remain at risk throughout high school. This is consistent with Collier and Thomas' (1999c) and Thomas and Collier's (2002) observations in their large-scale longitudinal study cited above, as well as Hakuta, Butler, and Witt's (2000) findings. We were alerted to this learner profile in our school by our principal, who noted and questioned their poor performance on the English 30 diploma examination in January 1998 (Roessingh \& Kover, 2002).

We identified a group of students about to enter grade 10 in our school of a similar learning profile and approached them to join us in the ESL program the following September (1998). Their trajectory is displayed in Figure 2, and again it reflects data found in the eight students' files. The single sharp trajectory noted after grade 10 is taken from consistent testing in the ESL program aggregated and averaged for the cohort.

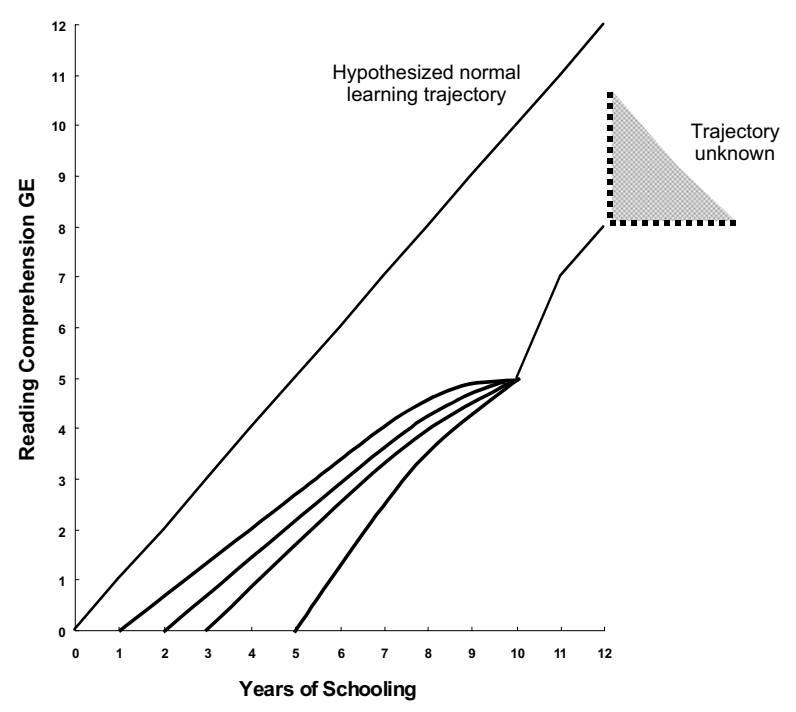

Figure 2. Trajectory of Cohort B: young arrivals, late intervention, $N=8$. Sources: CTBS, Alberta.

Achievement, Gates-MacGinitie, DRP. 
This cohort of eight young arrivals, the youngest of whom arrived in his grade 1 year, closely resembled cohort A depicted in Figure 1. At the end of their grade 9 year, these students were at heightened academic risk given their results on the provincial achievement tests. They were identified from these test results and invited to join the ESL program. Gates-MacGinitie( MacGinitie \& MacGinitie, 1992a, 1992b) reading tests were administered. We noted a close match between the vocabulary and reading comprehension scales, both at approximately GE 5. Over the next five semesters we noted a rapid growth in reading levels. They crossed two critical thresholds: GE 7 within the first year of the ESL program and GE 9 some time in the next three semesters, thereby making enormous progress in closing the cognitive gap as evidenced by the subscores of their English 30 examination (Roessingh \& Kover, 2003). Although the youngest arrivals had the greatest distance to make up, the results suggest that they succeeded in doing so. As one of the students remarked, it was at the GE 7 threshold that she finally had the "brain explosion" she had been waiting for. Even with rapid growth in reading ability and similar reading scores to the other cohorts, the youngest arrivals remain behind the older arrivals in terms of their performance on the grade 12 content examinations (English 30 and Mathematics 30), and they may remain at risk in postsecondary educational settings.

Figure 3 represents the performance of the 18 junior high-aged arrivals. These students entered school in Canada in grades 7-9 (aged 12-14). Some

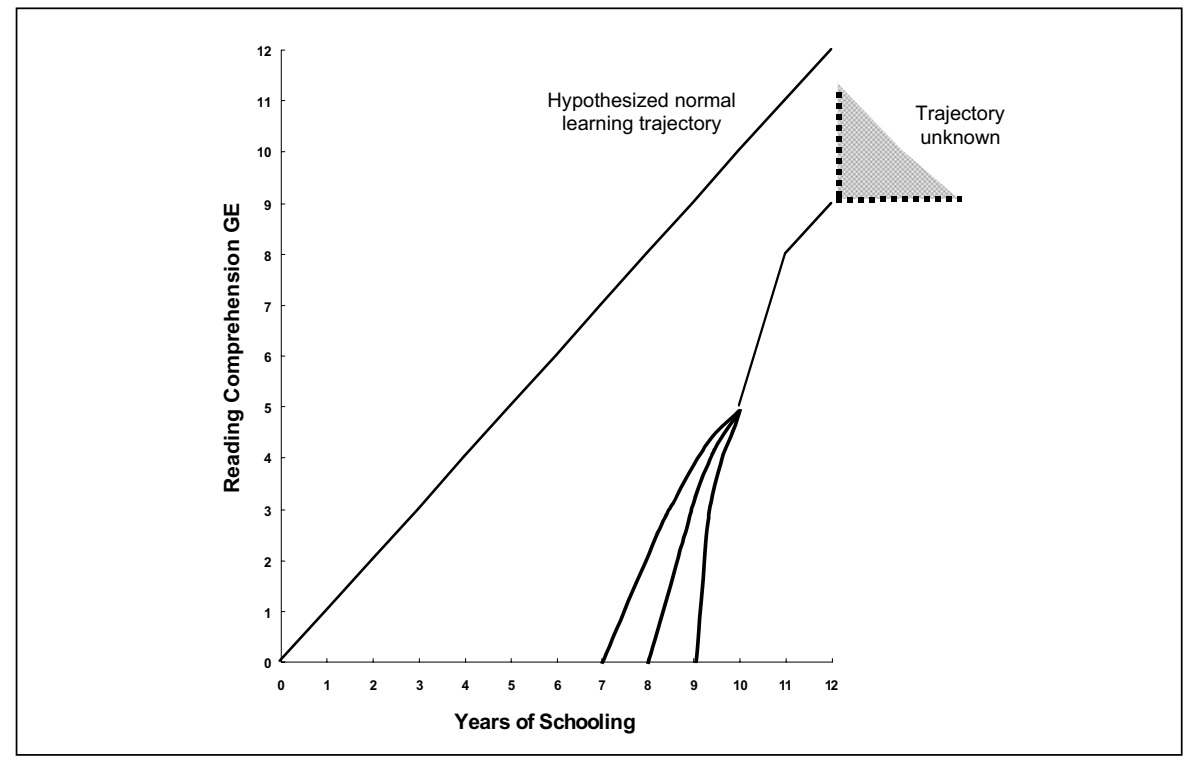

Figure 3. Trajectory of Cohort C: junior high (grades 7-9) arrivals $N=18$. Sources: CTBS, Alberta Achievement, DRP, Gates MacGinitie, SLEP. 
Table 4

David's Profile of Progress (Gates MacGinite scores)

\begin{tabular}{lcccc}
\hline Gates MacGinitie scores & Sept. '97 & Jan. '98 & June '98 & Jan. '99 \\
\hline Vocabulary & 2.7 & 4.5 & 4.5 & 5.6 \\
Comprehension & 4.8 & 4.6 & 7.3 & 8.6 \\
Total & 3.7 & 4.5 & 5.4 & 6.8 \\
\hline
\end{tabular}

had studied English as a foreign language (EFL) in their country of origin, but in general they were considered beginner learners of ESL on arrival. They continued to acquire ELP immersed in content-area classrooms in our school system, often with some ESL support. We found the quality and duration of this support inconsistent. We sometimes found the students resistant to further ESL support at the high school level. Their perceptions were at times in conflict with ours; they believed that communicative competence was sufficient for direct entry into all areas of content study. We recommended and stood firm on their need to improve their CALP in the context of the ESL program we were developing. Ultimately, most chose to follow the ESL program.

We noted a sharp increase in reading abilities in their grade 10 year. In their grade 11 year, despite good gains in reading comprehension, we noticed that their ability to make the kinds of gains they had made earlier

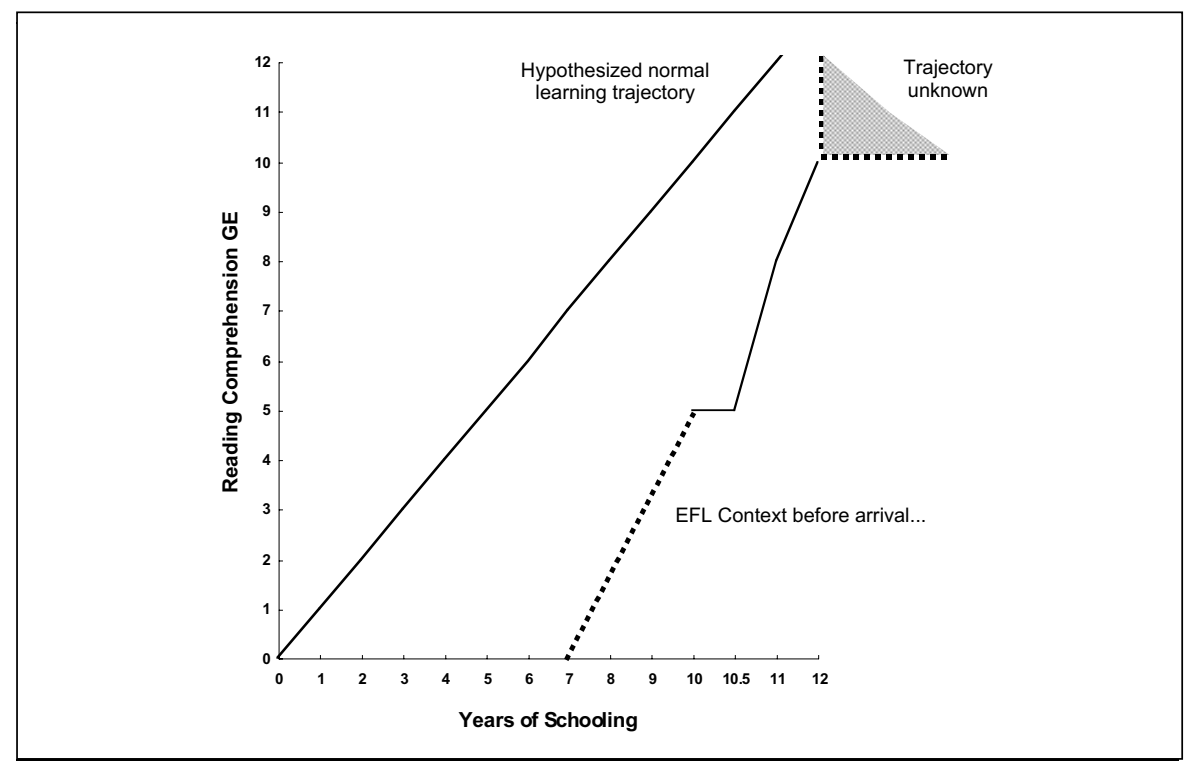

Figure 4. Cohort D: Late Arrivals $N=21$.

Sources: SLEP, Gates-MacGinitie, DRP. 
was diminishing. Their momentum began to level off as L2 overtook L1, perhaps because for the first time, language and concept development would have to occur without recourse to L1. They had reached the limits of their ability to profit from the benefits of advanced L1 curriculum in mathematics and sciences.

Figure 4 illustrates the learning trajectory of the 21 late arrivals (generally aged 16). Most of these students had studied EFL and had developed solid intermediate-level basic skills in their country of origin as depicted by the broken line before their grade 10 year. Two exceptions were noted: although they had the basic skills (BS) of the BICS equation, they lacked interpersonal communicative (IC) proficiency; and their vocabulary lagged behind their reading comprehension scores (GE5) by approximately 24 months.

The first semester showed no gains in reading comprehension. It appears that vocabulary development is the critical trigger for reading comprehension. Once the vocabulary measure exceeded approximately GE 5, reading comprehension scores rose rapidly. Although these students were already integrated into mathematics and sciences based on the theory that their prior knowledge in these areas would allow them to advance their ELP in this setting, their ability to access content-area materials meaningfully may ultimately be constrained by poor vocabulary and reading comprehension. Active deployment of reading strategies and higher-level thinking skills were evident in this cohort once they had reached the vocabulary threshold of about GE 5. Table 4 illustrates David's profile of reading progress, a good example of this phenomenon.

These findings are in keeping with research in the area of critical mass theory (Grabe, 1986) and with the suggested threshold of 2,000-3,500 core words (in English) for incidental and strategic acquisition of vocabulary through independent reading for ESL learners (Nation, 2001; Laufer, 1992; Cobb, 2002). NS children reach this threshold with a vocabulary of approximately 15,000 words (GE 5). ESL learners can only compete at this level if they already have the underlying proficiency demonstrated by an adequate L1 vocabulary.

Although most reading scores for cohort D reached GE 10-11 by their grade 12 year and they outdistanced the other cohorts on the English 30 examination, they too reached an apparent ceiling, but this time not attributable (we believe) to lack of CALP in L1 or L2. For all profiles of learners, the vocabulary measure lagged significantly even after they had crossed the initial threshold of GE 5, and the reading comprehension score increased rapidly. The complex and abstract (metaphoric) vocabulary inherent in advanced academic study that is often linked to conceptual data and semantically networked (as well as culturally constrained) presents a major hurdle for ESL learners, especially the younger arrivals who may not have recourse to L1 to support them. 


\section{Discussion}

This discussion is framed by our four orienting questions.

Language thresholds and academic achievement.

In their race to beat the academic time clock, all these students have "run faster" and "reached higher" than the range of time and the threshold required to develop CALP-like proficiency. Our overall target of $60 \%$ on the English 30 examination appears to be appropriate and manageable, given programmatic ESL support. This equates to at least GE 9 or the 65th percentile on a reading measure. Our data support earlier research, indicating the close connection between reading skills and academic achievement.

Important indicators of progress in the ESL program are reading scores of GE 5 (high intermediate-shifting from learning to read to reading to learn); GE 7 (integration into the grade 10 English language arts program - with ESL support); and GE 9. Nevertheless, we understand that $60 \%$ on the English 30 examination for a younger-arriving learner is qualitatively different from $60 \%$ for a student who arrives over the age of 15 , and the younger arrival may continue to be at academic risk in the future. This stems from the lack of depth in CUP (background knowledge) for younger arrivals: a GE 9 in itself is not sufficient ELP for future academic success at the university level. Moreover, "something more" on the English 30 examination cannot be mediated by language proficiency alone. In broad strokes, we think of this as cultural capital.

Although we think of all our students as exceptional, a few broke out of the mold entirely. For the first time in January 2002, we noted a mark in the English examination that was in the standard of excellence (over $80 \%$ ). This was achieved by a late-arriving male student from mainland China. Highly sought after by various universities (Waterloo, University of Toronto, McGill), this student is in his third year of computer engineering at the University of Toronto. Our fastest learner (from 0 to the 65th percentile in her reading score) was a woman, also late arriving - the lone learner from Kazakhstan. She came as a beginner ESL learner and closed the gap in just two years (1998-2000). She has graduated from the University in Calgary. One woman from mainland China—also late arriving_-doubled the speed of her language intake (as measured in her reading scores) in her grade 12 year and is currently in her third year in the Faculty of Management in the University of Calgary. This student benefited from a homestay setting that clearly enhanced her intake of English.

Division 2 (grades 4-6) students need to be targeted for ESL support, because this appears to be a stage of increased risk for low plateau and fossilization. They are not making the shift from learning to read to reading to learn and the associated cognitive shift from concrete to abstract thought. If these learners could be brought to the 65th percentile for their grade 
placement by the end of grade 6, we wonder if they would develop the momentum to sustain this kind of growth independently throughout junior high school (grades 7-9). This would need to be monitored, and if these students' progress has declined by grade 10, ESL support could be offered again at the high school level. Again, we believe they must reach a minimum GE 9 in their reading scores to access content information in grades 10-12. The accurate and accountable benchmarking of language proficiency for K-12-aged students represents a much-needed area of research (Harklau, 2003).

\section{The need for assessment instruments that reflect academic language proficiency}

Reading scores and content-area achievement grades do not give adequate insight into the development of CALP-like proficiency. As noted above, accountable and accurate benchmarking is an area of high priority for research, but the instruments required to capture this construct are not currently available. Although research, including our own, suggests that standard reading measures may be a good a place to begin, these do not consider the contribution of first-language proficiency that may account for the enormous variability at both the intake (GE 5 in this case) and outcome points (at least a GE 9 and 60\% in English 30) that are not immediately visible. There is a distinct dynamic among L1, L2, and educational achievement that prompts us to interpret the students' scores only in the light of what we know about all these factors in concert.

Clearly content-area achievement scores are culturally biased. This is inherent in these types of assessments. English 30 is a literature-based course that requires students to read at an interpretive, critical level. Although concepts such as loss, adversity, facing challenges, turning points, dreams, and identity are universalities of the human condition, they are understood in the particularities of the narratives valued by a culture, often embedded in metaphor. The experience of immigrating forces ESL students to acquire this cultural capital and metaphoric competence in the context of the English language arts program, most often with no direct ESL support. Increased reading scores may not mitigate the challenge of accessing the literature courses at advanced levels (grade 11 and 12 especially). So we doubt the equitability of English 30 as a measure of a student's English-language proficiency for the purposes of university admission. Significant numbers of our most gifted ESL students may not receive their rightful opportunity to pursue tertiary academic studies unless we address this issue.

The need for instructed support and time

Growth in language proficiency appears to be a function of ESL program participation and the quality of instructed support. At present, however, the funding/credit structures provided for ESL services by ministries of education do not represent the level of support required to achieve the thresholds 
for academic success identified in this study. As noted above, $625-750$ hours of program instruction at the high school level have a tangible effect on the educational achievement of arrivals of every age. Members of our profession must continue to advocate for our students and our programs on this front. We know that many, if not most, jurisdictions also face the vagaries of political decision-making that does not reflect the learning needs of immigrant students. We must continue to conduct longitudinal research and ESL program evaluations to identify the factors that make a difference to our students.

\section{The role of $A O A$, Common Underlying Proficiency, and the \\ the-younger-the-better myth}

We are not alone in noting the importance of AOA and CUP. Jiang and Kuehn (2001) report similar findings in a small-scale study (22 students) of intermediate-level ESL learners (determined by a pre-test) at the postsecondary level spanning one semester of English for academic purposes. The class was divided between older arrivals (13 students) who had completed their secondary schooling in their country of origin, and younger arrivals (9 students) who had completed approximately five years of schooling in L1 before immigrating. Overall, both groups made statistically significant gains by the end of the semester - attributed to the language instruction intervention-but the gains were realized differently when analyzed by subtest scores (e.g., listening test, writing test). The older-arriving group used more cognitive strategies (contextual guessing) and were better able to deploy higher-order thinking skills to solve problems (making inferences). The older arrivals' writing performance in vocabulary was also stronger than that of the younger arrivals. Jiang and Kuehn conclude that older arrivals made more progress than the early-arriving group and that separate classes for varying learner profiles might have resulted in better-targeted instruction.

In our teaching and learning context we arrive at different conclusions. Having looked at baseline data for the youngest-arriving ESL learners (Cohort A), we note that even given instructed support (Cohort B), young arrivals do not reach the same levels as the older arrivals (Jiang \& Kuehn, 2001). Younger arrivals actually had far more ground to cover: the challenge for them sometimes seemed overwhelming. Because we were able to base lessons on a broader framework of concepts, language, and strategies, it was possible to differentiate the focus according to learners' needs in our mixedneeds setting. From an instructional perspective, lessons need to be "big enough" for students to take what they need. Because we had developed the learner profiles in advance and we understood the significance of L1 development (Roessingh \& Kover, 2003), we were also often able to target instruction knowing well the student we were working with and his or her specific learning needs at any time. In our teaching context, budgetary constraints militate against smaller class sizes and the ability to separate the younger 
arrivals (cohorts B and C) from the older arrivals. More important, we became aware of an unexpected benefit of exposing the younger arrivals to the better L1 models presented by the older arrivals.

As the semesters passed, the groups intermingled, often choosing to interact in Cantonese (or Mandarin) and do their mathematics and science homework together over lunch and after school. The youngest arrivals' (cohort B) mathematics scores increased by 10 points compared with those of cohort A, young arrivals who had not received ESL support (Roessingh \& Kover, 2003). We wondered whether this increase might in part be attributable to increased use of L1 (which we had not thought to measure on intake), and also whether the impressive growth in L2 might also be partly attributable to enhanced L1. Benefits flowed from the younger arrivals to the older arrivals as well. The younger arrivals tended to be the fashionistas in the crowd. When it came time to prepare for the graduation banquet and dance, it was they who graciously and generously opened their clothes closets and makeup drawers to share dresses, strappy sandals, handbags, glitter makeup, and toenail polish and to share tips with the older arrivals as to the best hair designers in Chinatown. No one was left behind or left out.

The plight of the youngest arrivals is perhaps the most heartrending, yet clearly the area where the greatest gains can be made (recall Cohort A and B). The loss of so many youngsters' potential in school systems across Canada and the US needs to be understood as lost educational capital today, and lost human capital in the workplace of the future. Harklau (2003) notes that we know little about this learner profile, recently named "generation 1.5 " in the research literature.

In revisiting our orienting research questions, then, our work has moved us ahead in understanding the fragility of the underlying proficiency of the younger arrivals, the idea of language threshold levels needed for ongoing academic progress in high school, and the enormous challenge faced by our ESL learners as they seek to compete with their NS counterparts. Second, reading measures provide only partial information in the larger picture of academic success. Content achievement measures (i.e., the English departmental exam) are more telling by what they fail to measure, a view echoed in Garcia and Gopal's (2003) study. The work of devising assessment instruments and establishing benchmarks for ESL learners is a much-needed area of endeavor. Last, we have gained valuable insights into the benefits of programmatic support and time (625-750 hours) as critical elements of ESL instruction that can make a difference.

\section{Conclusion}

ESL success in developing CALP is a multifaceted challenge that is more than a matter of time, AOA, and L1 proficiency level. ESL success depends heavily on quality ESL programming, sequencing and distribution of course 
work, consideration for the overall workload of high school, strategic timetabling, collaborative working relationships among ESL teachers and their colleagues in the English department, teacher expertise, and administrative support. Learner variables are at play: work ethic and motivation, and critically the relationship between the teacher and the learners. Stakeholders are many: school administrators, ESL teachers, guidance counselors, mainstream educators, system- and ministry-level administrators, and of course the ESL learners themselves and their parents. Much work based on research remains to be done in curriculum and policy development. We would welcome large-scale longitudinal studies that track ESL learners over the entire spectrum of their schooling experiences, carefully linking progress to the types of instructed support that make a difference. We need measuring instruments designed to do this work, and we need to work toward consistent benchmarking of learner outcomes that will point to the critical thresholds along the way that signal future success.

Our work corroborates the findings of others. Our ESL learners too were in the range for developing CALP that has been documented earlier. In fact, to develop CALP in only five semesters means an accelerated learning pace that is made clearly visible by the trajectories we provide in Figures 1-4. To realize these gains means enormous work on the part of our learners. To realize these gains also means a significant commitment of instructional time that is currently not funded, and thoughtful, intentional planning on the part of teachers. Documenting this journey is the purpose of this article. Hence we have a better understanding of how the five- to seven-year time range suggested when starting from beginner-level proficiency, BICS, may take the first two years. We note that the language threshold for academic success is significantly higher than that set by other researchers, but it is an achievable goal.

It is time the responsibility for educating ESL learners was returned to the provincial ministerial level, perhaps in conjunction with federal-level funders who set immigration policy and immigration levels. We need a coordinated, concerted national effort to address the many issues that face ESL learners in our K-12 systems across Canada. Senior-level administrators must find the political will and courage to advance these issues in the policy arena. And it is time we stopped blaming the victim. It is not unreasonable that immigrant parents arriving today with the credentials, academic preparation, and previous high socioeconomic status that made them such desirable immigrants should expect and hope that their children will achieve as they would have if they had not accepted Canada's invitation-an education and a secure future. The failure of so many children to meet these expectations is less a reflection on them and much more a reflection of systemic educational neglect that has seen the decimation of ESL programs across large urban school jurisdictions over the past decade. We must turn 
the tide by establishing programmatic support capable of demonstrating accountable and equitable educational achievement.

Meanwhile, we take comfort and pride in knowing that practitioners in classrooms can quietly but firmly take charge and make change from the bottom up for ESL learners in their classrooms.

\section{Acknowledgments}

The authors thank the principal of the school Diane Field for her concern, care, and support of the ESL and English Department's work in improving teaching and learning for ESL students. Her monitoring of the English examination in January 1998 alerted us to the need to identify the ESL at-risk young arrivals and to reclaim the potential of the youngest-arriving ESL learners in our school. We thank Jim Cummins for taking the time to read and to provide encouraging feedback on an earlier draft of the article. As well, the feedback from anonymous readers who reviewed our manuscript for the TESL Canada Journal has been helpful in strengthening the presentation of our work.

\section{The Authors}

Hetty Roessingh is a long-time ESL practitioner with the Calgary Board of Education. Her interests in classroom-based research have evolved from tracking to curriculum design and development, materials design and development to assessment, and always advocacy. In July 2000, Hetty joined the Faculty of Education, University of Calgary, where she teaches in the MEd TESL program.

Pat Kover is on the administrative team at Queen Elizabeth High School, Calgary. Previously Pat was the English Department Head at Queen Elizabeth, and her interest in classroom-based research as a way of understanding teaching and learning for ESL students in mainstream settings made for a natural collaboration with the ESL program. Pat is currently enrolled in doctoral studies at the University of Calgary.

David Watt is an associate professor in the Faculty of Education, University of Calgary. He teaches in the MEd TESL program. His research interests include rates of second-language acquisition among adult learners and thresholds for various occupational profiles.

\section{References}

Alberta Learning. (2002). English as a second language, Guide to implementation. Edmonton, AB: Author.

Baxter, J. (1999). Canada recruiting the educated: Policy creating "brain gain" in sciences. Calgary Herald, December 11.

Chamot, A. (1995). Implementing the cognitive academic language learning approach: CALLA in Arlington, Virginia. Bilingual Research Journal, 19(3\&4), 379-394. Retrieved August 5 , 2003, from:http://www.ncela.gwu.edu/miscpubs/nabe/brj/v19/index.htm\#34

Chamot, A., \& O'Malley, M. (1987). The cognitive academic language learning approach. TESOL Quarterly, 21, 227-247.

Chamot, A., \& O'Malley, M. (1994). The CALLA handbook: Implementing the cognitive academic language learning approach. Don Mills, ON: Addison-Wesley.

Cobb, T. (2002). Review of Paul Nation, Learning vocabulary in another language. Retrieved June 3, 2003, from:http:/ / www.er.uqam.ca/nobel/r21270/cv/Nation_2001.htm

Coelho, E. (2003). Adding English: A guide to teaching in multilingual classrooms. Toronto, ON: Pippin.

Collier, V. (1987/1988). The effect of age on acquisition of a second language for school. National Clearinghouse for Bilingual Education, Focus, 2, Winter 1987/1988. Retrieved August 5, 2003, from: http:/ / www.ncela.gwu.edu/ncbepubs/classics/focus/02aage.htm 
Collier, V. (1992). A synthesis of studies examining long-term language minority student data on academic achievement. Bilingual Research Journal, 16(1\&2), 187-212. Retrieved August 5, 2003,from:http://www.ncela.gwu.edu/miscpubs/nabe/brj/v16/16_12_collier.htm

Collier, V. (1995). Acquiring a second language for school. National Clearinghouse for Bilingual Education, Directions in Language and Education, 1(4). Retrieved August 5, 2003, from: http://www.ncela.gwu.edu/ncbepubs/directions/04.htm

Collier, V., \& Thomas, W. (1999a). Making U.S. schools effective for English language learners, Part 2. TESOL Matters, 9(5). Retrieved August 1, 2002, from: http://www.tesol.org/pubs/articles/1999/tm9910-01.html

Collier, V., \& Thomas, W. (1999b). Making schools effective for English language learners, Part 3. TESOL Matters, 9(5), December-January 2000. Retrieved August 1, 2002, from: http://www.tesol.org/pubs/articles/1999/tm9912-01.html

Collier, V., \& Thomas, W. (1999c). Making U.S. schools effective for English language learners, Part 1. TESOL Matters, 9(4). Retrieved August 1, 2002, from: http:/ / www.tesol.org/pubs/articles/1999/tm9908-01.html

Cummins, J. (1982). Bilingualism and minority language children. Toronto, ON: OISE Press.

Cummins, J. (1996). Negotiating identities: Education for empowerment in a diverse society. Ontario, CA: California Association for Bilingual Education.

Cummins, J. (1999). BICS and CALP. Retrieved August 1, 2002, from: http://www.iteachilearn.com/cummins/bicscalp.html

De Avila, E. (1997). Setting expected gains for non and limited English proficient students. Retrieved August 5, 2003: http://www.ncela.gwu.edu/ncbepubs/resource/setting/index.htm

De George, G. (1987/1988). Assessment and placement of language minority students: Procedures for mainstreaming. National Clearinghouse for Bilingual Education, Focus, 3, Winter 1987/1988. Retrieved August 5, 2003, from: http://www.ncela.gwu.edu/ncbepubs/classics/focus/03mainstream.htm

DeVries, J. (1999). Foreign born language acquisition and shift. In S. Halli \& L. Dredger (Eds.), Immigrant Canada: Demographic, economic and social challenges (pp. 261-281). Toronto, ON: University of Toronto Press.

English language education for immigrant children. (2001). Retrieved October 1, 2002, from: http:/ / www.leginfo.ca.gov/calaw.html

Frye, N. (1963). The educated imagination. Massey Lecture Series. Toronto, ON: Canadian Broadcasting Corporation (CBC).

Garcia, G. (2000). Lessons from research: What is the length of time it takes limited English proficient students to acquire English and succeed in an all-English classroom? National Clearinghouse for Bilingual Education, Issue and Brief, No. 5, September 2000. Retrieved August 4, 2003, from: http:/ / www.ncela.gwu.edu/ncbepubs/issuebriefs/ib5.htm

Garcia, P., \& Gopal, M. (2003). The relationship to achievement on the California High School exit exam for language minority students. NABE Journal of Research and Practice, Winter, 123-137. Retrieved June 3, 2003, from: http:/ / www.uc.edu/njrp

Grabe, W. (1986). The transition from theory to practice in teaching reading. In F.Dubin, D.E. Eskey, \& W. Grabe (Eds.), Teaching second language reading for academic purposes (pp. 25-48). Reading, MA: Addison-Wesley.

Hakuta, K., Butler, Y. \& Witt, D. (2000). How long does it take English learners to attain proficiency? ERIC Document Reproduction Service No. ED 443275.

Harklau, L. (2003). Generation 1.5 students and college writing. Retrieved April 19, 2004, from: http:/ / www.cal.org/resources/digest/0305harklau.html

Jiang, B., \& Kuehn, P. (2001). Transfer in the academic language development of post-secondary ESL students. Bilingual Research Journal, 25(4), 1-17. Retrieved August 1, 2002, from: http:/ / brj.asu.edu/v254/articles/art12.html

Klesmer, H. (1994). Assessment and teacher perceptions of ESL student achievement. English Quarterly, 26(3), 8-11. 
Lambert, W. (1969). Some cognitive consequences of following a first-grade curriculum in a second language. Journal of Educational Psychology, 60(2), 86-96.

Laufer, B. (1992). How much lexis is necessary for reading comprehension? In P.J. Arnaud \& H. Bejoint (Eds.), Vocabulary and applied linguistics (pp. 126-132). London: Macmillan.

MacGinitie, W., \& MacGinitie, R. (1992a). Gates-MacGinitie Reading Tests 2nd ed., levels E and F. Scarborough, ON: Nelson Canada.

MacGinitie, W., \& MacGinitie, R. (1992b). Gates-MacGinitie Reading Tests, 2nd ed., Teachers' Manual. Scarborough, ON: Nelson Canada.

Marshall, A. (1999). Alberta attracting more immigrant entrepreneurs. Calgary Herald, February 15.

Ministry of Education and Training, Ontario. (1999). The Ontario curriculum grades 9 to 12. English as a second language and English literacy development. Retrieved August 1, 2002, from: http://www.edu.gov.on.ca

Mohan, B. (1990). LEP students and the integration of language and content: Knowledge structure and tasks. Retrieved August 1, 2002, from: www.ncela.gwu.edu/ncbepubs/symposia/first/lep.htm

Moskowitz, B. (1978). The acquisition of language. Scientific American, November, pp. 92-108.

Nation, P. (2001). Learning vocabulary in another language. Cambridge, UK: Cambridge University Press.

Roessingh, H. (1996). ESL: Inclusive high school science class. Unpublished doctoral dissertation. University of Calgary.

Roessingh, H. (1999). Adjunct support for high school ESL learners in mainstream English classes: Ensuring success. TESL Canada Journal, 17(1), 72-86.

Roessingh, H., Ehler, P., Watt, D., \& Nettel-Aguirre, A. (2004). ESL students in tertiary education programs: An exploratory study at the University of Calgary. Unpublished manuscript.

Roessingh, H., \& Field, D. (2000). Time, timing, timetabling: Critical elements of successful graduation of high school ESL learners. TESL Canada Journal, 18(1), 17-31.

Roessingh, H., \& Kover, P. (2002). Working with younger arriving ESL learners in high school English: Never too late to reclaim potential. TESL Canada Journal, 19(2), 1-20.

Roessingh, H., \& Kover, P. (2003). Variability of ESL learners' acquisition of cognitive academic language proficiency: What can we learn from achievement measures? TESL Canada Journal, 21(1), 1-21.

Saville-Troike, M. (1991). Teaching and testing for academic achievement: The role of language development. NCBE Focus: Occasional Papers in Bilingual Education, 4, spring. Retrieved August 5, 2003, from: http:/ / www.ncela.gwu.edu/ncbepubs/focus/focus4.htm

Shoebottom, P. (2001). Second language acquisition. Retrieved June 2, 2003, from: http://www.fis.edu/eslweb/index.htm

Tetley, D. (2004). Students clamour for their education: Cutbacks in land of plenty protested. Calgary Herald, November 19.

Thomas, W., \& Collier, V. (2002). A national study of school effectiveness for language minority students' long-term academic achievement. Retrieved October 1, 2002, from: http:/ / www.crede.ucsc.edu/research/llaa/1.1_es.html

Thompson, M. et al (2002). Exito en California? A validity critique of language program evaluations and analysis of English learner test scores. Retrieved October 1, 2002, from: http://epaa.asu.edu/epaa/v10n7

Twyford, C. (1987/1988). Age-related factors in second language acquisition. National Clearinghouse for Bilingual Education, Focus No. 2, Winter. Retrieved August 1, 2002, from: http://www.ncela.gwu.edu/ncbepubs/classics/focus/02bage.htm

Watt, D., \& Lake, D. (2000). Canadian language benchmarks-TOEFL Research Project. A comparison of the Canadian Language Benchmarks and the Test of English as a Foreign Language. Calgary, AB: University of Calgary.

Watt, D., \& Roessingh, H. (2001). The dynamics of ESL dropout: Plus ca change ... Canadian Modern Language Review, 58, 203-222. 


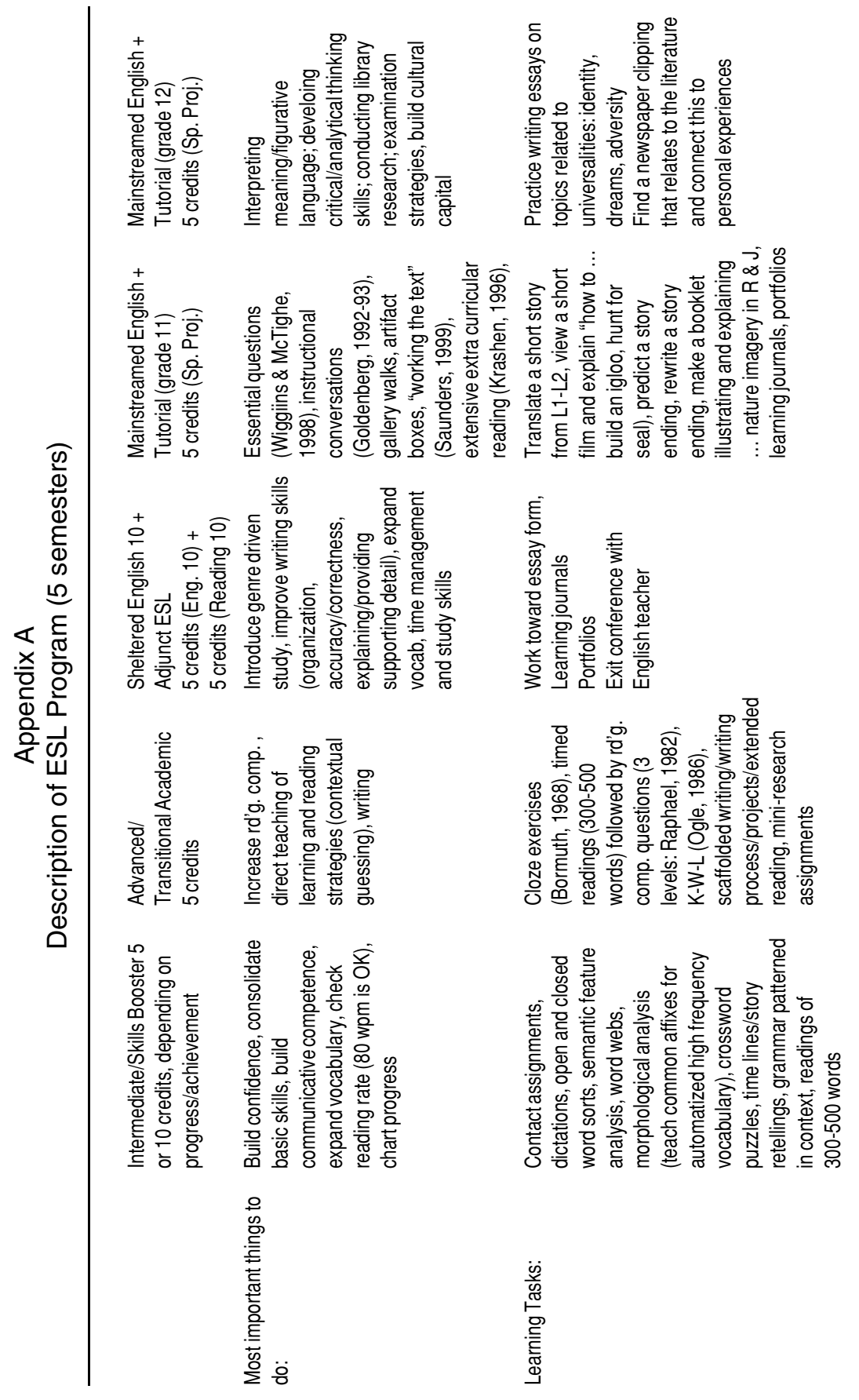



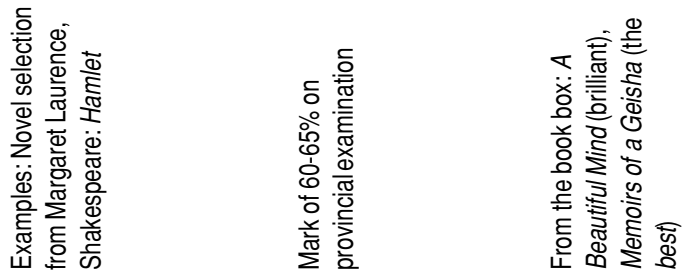

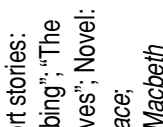

든 를 ¿

क

ฆ

产离

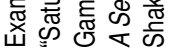

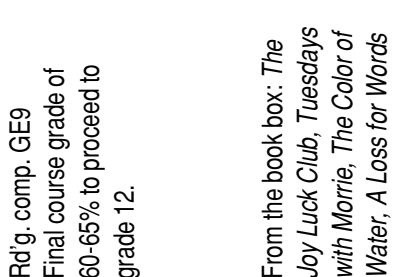

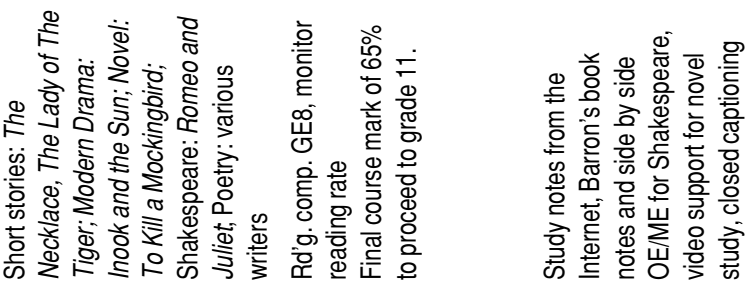

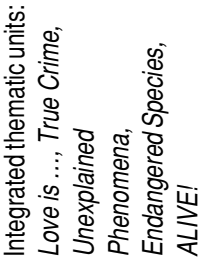

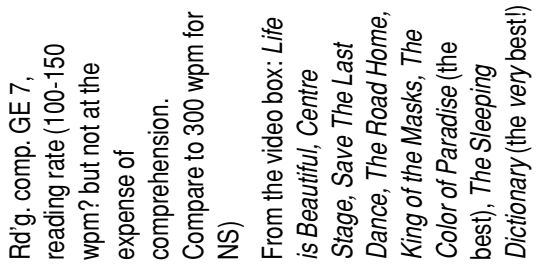

i) बे के

गे

음 $\frac{0}{\mathbb{1}}$ 迹

迹赵

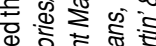

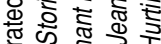

兽胥迹峦

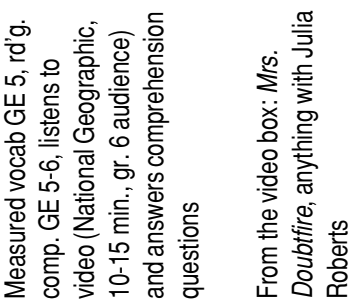

홍

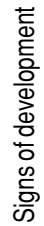

$\frac{0}{0}$
$\frac{0}{0}$
$\frac{0}{0}$
$\frac{0}{0}$
$\frac{0}{0}$
क 


\section{Appendix B}

A sample template for a three-year high school program based on a semester system

Semester 1

Grade $10^{1}$

ESL

ESL or CTS ${ }^{2}$

PE 10

Math 10
Grade 11

English 10: sheltered

ESL Adjunct

Soc. Studies 23

Physics, Math or Chemistry 20
Grade 12

English 20 or English 30

ESL tutorial

Math 30

Physics 30 or Chemistry 30 or Biology 20

\section{English 30}

ESL tutorial

Chemistry 30 or Physics 30

Math 31 or Biology 30

Summer school:

Biology 30 ?

Math 20 or

Math 20 or

Soc. Studies 33

Physics, Math or Chemistry 30

Summer school:

Physics 20 or

Chemistry 20

Chemistry 20

${ }^{1}$ Courses beginning with a "1" are grade 10 level, "2": grade 11, "3" grade 12. Courses ending in " 0 " are academic track courses, those ending in " 3 " are nonacademic track. Math 31 is an advanced calculus course required by the Faculty of Engineering.

${ }^{2}$ Career and Technology Studies: note that students must present 10 credits (the equivalent of two full courses) in CTS for graduation requirements. Many students can do this by presenting Chinese credits earned at Saturday school or by challenging the Chinese exam set by the local school board. Some students decide to focus on university faculty entrance requirements, and forfeit a high school diploma. No faculty requires CTS credits.

Note. Alberta Learning allocates only 15 credits (the equivalent of three full courses of 125 instructional hours each) for ESL programming at the high school level. Other credits, such as Reading 10, Communications $21 \mathrm{~A} / \mathrm{B}$ may be assigned to students' instructional programs. ESL students, however, often spend hundreds of hours in ESL class settings for no credit. ESL students capture the full funding for credit equivalent units (CEUs) whether or not their ESL time is assigned credit For more information on credit equivalents and course requirements for graduation, consult the Alberta Learning websites:

www.alis.gov.ab.ca or http://ednet.edc.gov.ab.ca 